\title{
BACTERIOLOGICAL QUALITY OF DRILLING WATER INTENDED FOR HUMAN CONSUMPTION IN FOUR PREFECTURES IN THE SAVANNAH REGION OF TOGO
}

Banfitebiyi GAMBOGOU ${ }^{1,2 *}$, Raouf Tonyi MENSAH ${ }^{1,2}$, Messanh KANGNI-DOSSOU $^{1}$, Bouraïma DJERI ${ }^{1}$, Yaovi AMEYAPOH ${ }^{*}$

Address (es):

${ }^{1}$ Laboratoire de Microbiologie et de Contrôle qualité des Denrées Alimentaires (LAMICODA), Ecole Supérieure des Techniques Biologiques et Alimentaires.

${ }^{2}$ Institut Togolais de Recherche Agronomique (ITRA), Direction des Laboratoire, Laboratoire de Contrôle Qualité des Aliments.

Corresponding author: dinhog39@gmail.com

ABSTRACT

$\underline{\text { https://doi.org/10.36547/be.331 }}$

According to the latest SDG recommendations, guidelines on access to safe drinking water have enabled the construction of boreholes in remote areas of developing countries. In Togo, particularly in the savannah region where access to drinking water remains a major problem for the population, many boreholes have been built for this purpose. The objective of this study is to evaluate the bacteriological quality of the waters of some boreholes built in four (04) prefectures of the savannah region in Togo.

A total of 68 samples of drilling water intended for human consumption were collected between January and February 2019 for bacteriological analysis. These analyses were carried out according to the standardized routine methods of the French Association for Standardization (AFNOR). The parameters sought or counted in these samples are those retained by the 2007 European Union criteria for water intended for human consumption. The analysis reveal that the samples of borehole water are at $50 \%$ and $90 \%$ of unsatisfactory hygienic quality respectively compared to the Total Coliforms (CT) and the Total Aerobic Mesophilic Flora (FAMT) which are indicative germs of hygiene failure. The correlation of the germs sought made it possible to distinguish two groups of indicators of contamination: those responsible for hygiene failures and old fecal contamination (ASR)

Conclusion: Since the majority of the borehole water analyzed is contaminated by germs indicating hygiene deficiencies, adequate treatment of these waters and monitoring of their quality are necessary in order to protect the population of the savannah region against probable diseases linked to faecal contamination germs.

Keywords: water, bacteriological quality, germs indicators of hygiene failure, Savannahs Region, Togo

\section{INTRODUCTION}

Water is an essential resource for the basic needs of man and his environment. It is a factor in economic and social development that has no substitute. For example, one of the points of the United Nations Millennium Development Goals (MDGs) has been to halve the number of people without access to safe water. Therefore, drinking water must comply with hygienic, chemical and even organoleptic quality standards (Fisher et al., 2020). When drinking water does not meet these quality standards, it can cause water-borne infections including cholera (Ocheli et al., 2020), bloody diarrhea (Antwi-Agyei et al., 2016), dysentery, hepatitis, typhoid fever and certain virus diseases (Ngure et al., 2019).

While water-related diseases have largely been eliminated in developed countries, they remain one of the leading causes of death in developing countries, particularly in Africa (Soncy et al., 2019). Five million deaths per year are believed to be due to waterborne diseases, including two million deaths of children under five years of age (WHO, 2019a). Larger quantities of water and a reduction in the risk of contamination of the water consumed are two of the predominant elements for a better prevention of the faecal danger, which is the main cause of diarrhoeal diseases that constitute a real scourge in African cities (Ocheli et al., 2020; Toure et al., 2019). These problems are exacerbated in urban areas, due to a combination of aggravating factors: high density of unhealthy housing, lack of sanitation, pollution of unprotected water sources (Igbinosa and Aighewi, 2017).

In African cities, the challenge is immense with more than 150 million urban dwellers still lacking access to a drinking water service, i.e. nearly half of the continent's urban population (WHO, 2019a). Given the poverty and the expected strong urban growth, there is a risk that the gap between the supply and demand for drinking water will widen even further (Kumpel et al., 2016). We can then ask ourselves to what extent, living tomorrow in an African city where water will be available in sufficient quantity and of good quality does not meet the challenge, when the question of access to healthy water is already raised with a particular priority, or even in degradation (Igbinosa and Aighewi, 2017; WHO, 2019b). In Togo, particularly the savannah region, the poorest area of Togo (DGSCN, 2007) drilling technology represents a significant advance in hygiene for the supply of water. Thus, in order to improve access to drinking water, regular and permanent monitoring of the water distribution system must be carried out in order to detect in time any failure that could lead to water pollution in order to guarantee the safety of consumers (Djeri $\boldsymbol{e t}$ al., 2019). It is in this approach that we evaluated the bacteriological quality of the water for human consumption from drilling in four prefectures of the savannah region in Togo.

\section{MATERIALS AND METHODS}

\section{Scope of the study}

The savannah region is the northern region of Togo with an area of $8,602 \mathrm{Km}^{2}$, with 659,444 inhabitants (in 2006) and a density of 77 inhabitants / $\mathrm{Km}^{2}$. This region is formed by a savanna vegetation of exceptional flatness, interspersed with green mountain rich in rock damains.

According to the study carried out by the Ministry of Economy and Finance as part of the "revised interim poverty reduction strategy paper for Togo", the poverty rate is $90.5 \%$ in the savannah region (DGSCN, 2007; Kankandja and Sokemawu, 2017) which does not allow the population to have access to drinking water from the TdE (Togolese Water Company).

\section{Hardware}

The sampling equipment consists of $500 \mathrm{ml}$ vials sterilized at $121{ }^{\circ} \mathrm{C}$ for 20 minutes, a cooler containing cold accumulators and a gas burner for aseptic sampling in the field.

A total of 68 borehole water samples were taken randomly from January to February 2019 in four prefectures of the savannah region: Kpendjale, Oti, Tandjoaré, Tône (Figure 1).

\section{Collection of water samples}

In order to properly take the samples, the iso 19458 method was used. A source or faucet was chosen closer to the main outlet line. At the taps, the tip is sterilized with a gas burner before sampling. The water is allowed to flow until a constant temperature is obtained, then taken directly from the sterile vial. The bottle is filled so as to allow the appropriate stirring before the analysis, i.e., $9 / 10$ of the volume. The bottle is closed immediately after sampling.

The samples were then stored in coolers containing the cold accumulators and transported to the laboratory. 


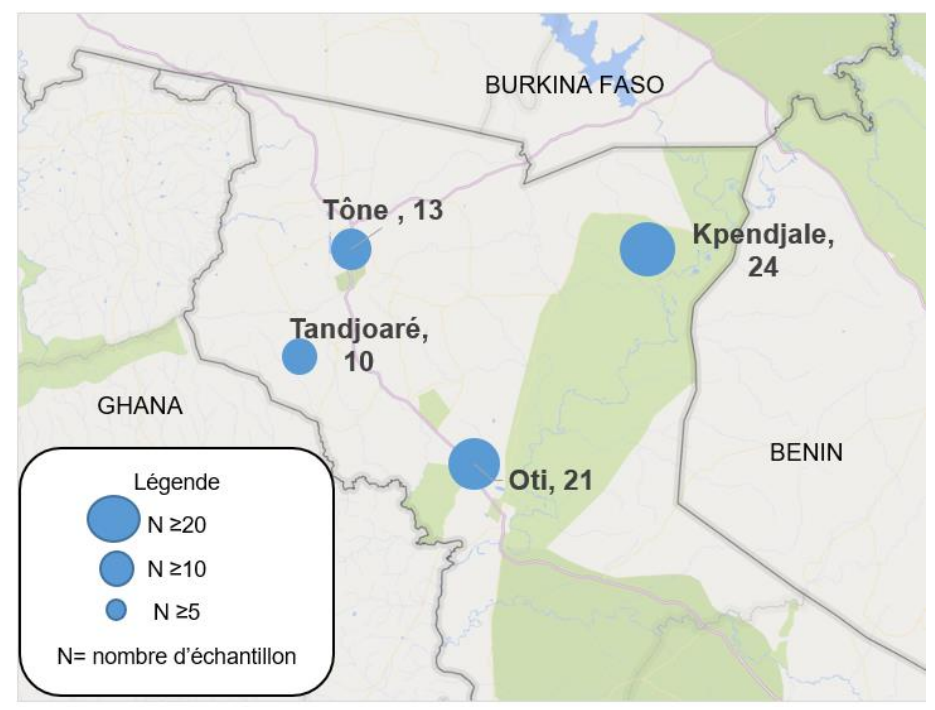

Figure 1 Map of the distribution of the number of samples taken by prefecture in the savannah region

\section{Bacteriological analysis of water samples}

The routine standardized methods of the French Association for Standardization (AFNOR) were used for the research and enumeration of contaminant germs in water (Table 1). The mass seeding method was used for the search and enumeration of germs selected for analysis in accordance with the criteria of the European Union taking into account the specificity (specific method of analysis) of each germ. The expression of the results was carried out according to ISO 7218 (2017). The oxoid brand culture media (France) used and the specific references of the methods of analysis of each germ are presented in the table below.

$\underline{\text { Table } 1 \text { Germs searched and enumeration methods in the waters analyzed }}$

\begin{tabular}{|c|c|c|c|}
\hline Germs sought & $\begin{array}{c}\text { Culture } \\
\text { media }\end{array}$ & $\begin{array}{c}\text { Standardized } \\
\text { methods }\end{array}$ & $\begin{array}{c}\text { Temperature/Incu } \\
\text { bation Time }\end{array}$ \\
\hline $\begin{array}{l}\text { Total mesophilic } \\
\text { aerobic flora } \\
\text { (FAMT) }\end{array}$ & PCA & $\begin{array}{l}\text { NF V08-051, } \\
\text { Feb. } 1999\end{array}$ & $30^{\circ} \mathrm{C} / 72 \mathrm{~h}$ \\
\hline Total coliforms (CT) & VRBL & $\begin{array}{l}\text { NF V08-050, } \\
\text { Dec. } 1992\end{array}$ & $30^{\circ} \mathrm{C} / 24 \mathrm{~h}$ \\
\hline $\begin{array}{l}\text { Thermotolerant } \\
\text { coliforms (Cth) }\end{array}$ & VRBL & $\begin{array}{l}\text { NF V08-016, } \\
\text { Dec. } 1992\end{array}$ & $44^{\circ} \mathrm{C} / 24 \mathrm{~h}$ \\
\hline $\begin{array}{l}\text { faecal Streptococci } \\
\text { (Sf) }\end{array}$ & $S \& B$ & $\begin{array}{l}\text { NF T } 90-416 \text {, } \\
\text { Oct. } 1985\end{array}$ & $37^{\circ} \mathrm{C} / 48 \mathrm{~h}$ \\
\hline $\begin{array}{l}\text { Anaerobic sulphite- } \\
\text { reducers (ASR) }\end{array}$ & TSN & $\begin{array}{l}\text { XP V08-061, } \\
\text { Av. } 1996\end{array}$ & $44^{\circ} \mathrm{C} / 48 \mathrm{~h}$ \\
\hline
\end{tabular}

Legends : PCA : Plate Count Agar ; VRBL : Violet Red Bile Lactose Agar ; S\&B : Slanetz and Bartley; TSN : Tryptone Sulphite Neomycin.

\section{Statistical analysis}

The statistical analysis was performed using SPSS v25 software. Pearson's crosstab and ${ }^{\mathrm{koh}-2}$ were used to compare test results by prefecture. Pearson correlation analysis and principal component analysis showed the existing correlations between the different germs sought and grouped them together.

\section{RESULTS}

Analysis of the bacteriological quality of borehole water samples in the savannah region

In total, 68 samples were analyzed including 10 samples from the prefecture of Tandjoaré, 21 from the prefecture of Oti, 24 from the prefecture of Kpendjale and 13 from the prefecture of Tône with respectively $90 \%, 50 \%, 19 \%$ and $12 \%$ of noncompliant sample compared to the Flora Aerobe Mesophilic Total (FAMT), the C-shaped Total (CT), the thermotolerant coliforms (Cth), the Anaerobic Sulfito-Reducer (ASR). But compared to Salmonella sp., E. coli and Faecal Streptococcus (Sf) no nonconformities were observed in all samples. In Figure 2, the prefectures of Oti, Tône, Kpendjale and Tandjoaré recorded respectively $100.0 \%(21 / 21), 92.3 \%$ (12/13), 91.7\% (22/24) and 60\% (6/10) of non-compliant samples compared to the FAMT with a $\mathrm{P}$ value of $0.007(\mathrm{P}<0.05)$. Concerning total coliforms (Fig. 3b), the prefectures of Tône $(69.2 \%$; 9/13), Kpendjale $(45.8 \% ; 11 / 24)$, Tandjoaré $(20 \% ; 2 / 10)$ and Oti $(57.1 \% ; 12 / 21)$ recorded different values of non-compliance with a $\mathrm{P}$ value of $0.106(\mathrm{P}>0.05)$. On the Fig. $3 \mathrm{c}$, relating to thermotolerant coliforms, the prefectures that obtained samples that did not comply with the criteria considered were the prefectures of Tône $(23.1 \%$; $3 / 13)$, Kpendjale $(29.2 \% ; 7 / 24)$ and Oti $(14.3 \% ; 3 / 21)$ with a $\mathrm{P}$ value equal to 0.223 ( $P>0.05$ ). The Sulfito-Reducer Anaerobes (ASR) represented on the Fig. 3d, show that only the samples from the prefecture of Tône $(46.2 \% ; 6 / 13)$ and Oti $(9.5 \% ; 2 / 21)$ show non-conformities with regard to the criteria considered with a $\mathrm{P}$ value equal to $0.000(\mathrm{P}<0.05)$. Compared to faecal streptococci $(\mathrm{Sf})$, every 68 (100\%) analyzed samples are compliant (Fig. 3(e).

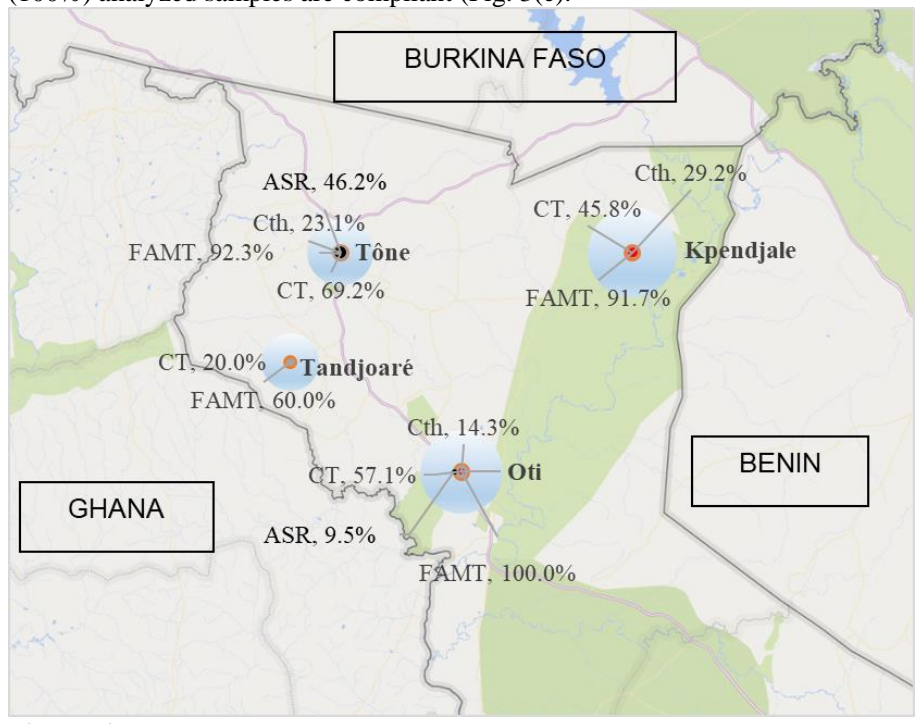

Figure 2 Map of the distribution of the percentage of non-compliance of microbiological quality according to the germs sought in each prefecture.

Legend : FAMT : Flora Aerobic Mesophilic Total, CT : Total coliforms, Cth : Thermotolerant coliforms, ASR : Anaerobic Sulfito-Reducer.

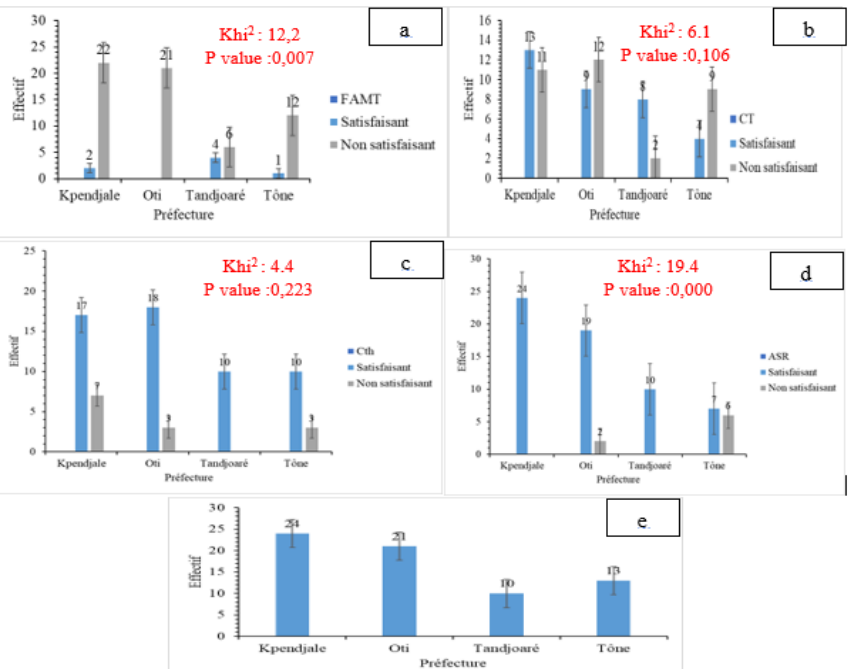

Figure 3 Assessment of the quality of the drilling water analyzed in the four prefectures.

Legend :

a. FAMT : Flora Aerobic Mesophilic Total,

b. CT : Total coliforms,

c. Cth : Thermotolerant coliforms,

d. ASR : Anaerobics Sulfito-Reducers,

e. Sf: faecal Streptococcuss . 


\section{Correlations Analysis of the germs sought}

Descriptive statistical analysis is shown in Table 2. The average germs sought are respectively $11008.34 \mathrm{CFU} / \mathrm{ml}$ for FAMT, $17.72 \mathrm{CFU} / \mathrm{ml}$ for CT, 11.12 CFU / $\mathrm{ml}$ for Cth, and $0.68 \mathrm{CFU} / \mathrm{ml}$ for ASR. Analysis of Pearson correlations (Table 3 ) between the germs sought showed a significant correlation $(\mathrm{p}<0.05)$ between the FAMT, CT and Cth. The Pearson correlation coefficients between FAMT and CT, FAMT and Cth, CT and Cth are respectively 0.526, 0.449 and 0.976.
Table 2 Descriptive Statistical Analysis

\begin{tabular}{lc|c|c}
\hline & $\begin{array}{c}\text { Average } \\
(\mathrm{CFU} / \mathrm{ml})\end{array}$ & $\begin{array}{c}\text { Standard } \\
\text { deviation } \\
(\mathrm{CFU} / \mathrm{ml})\end{array}$ & Analysis N \\
\hline Flora Aerobic Mesophilic Total & 11008,34 & 14307,12 & 68 \\
\hline Total coliforms & 17,72 & 39,27 & 68 \\
\hline Thermotolerant coliforms & 11,12 & 33,10 & 68 \\
\hline Faecal streptococci & 0,01 & 0,12 & 68 \\
\hline Anaerobics sulphito-reducings & 0,68 & 2,09 & 68 \\
\hline
\end{tabular}

Table 3 Pearson correlation of the desired germs

\begin{tabular}{|c|c|c|c|c|c|c|}
\hline & & FAMT & $\mathrm{Ct}$ & Cth & Sf & asr \\
\hline \multirow{3}{*}{ Flora Aerobic Mesophilic Total (FAMT) } & Pearson correlation & 1 & $0.526^{* *}$ & $0.449^{* *}$ & 0,043 & $-0,012$ \\
\hline & GIS. (bilateral) & & 0,000 & 0,000 & 0,728 & 0,920 \\
\hline & $\mathrm{n}$ & 68 & 68 & 68 & 68 & 68 \\
\hline \multirow{3}{*}{ Total Coliforms (CT) } & Pearson correlation & $0.526^{* *}$ & 1 & $0.976^{* *}$ & 0,217 & 0,069 \\
\hline & GIS. (bilateral) & 0,000 & & 0,000 & 0,075 & 0,577 \\
\hline & $\mathrm{n}$ & 68 & 68 & 68 & 68 & 68 \\
\hline \multirow{3}{*}{ Thermotolerant coliforms (Cth) } & Pearson correlation & $0.449^{* *}$ & $0.976^{* *}$ & 1 & 0,226 & 0,031 \\
\hline & GIS. (bilateral) & 0,000 & 0,000 & & 0,063 & 0,803 \\
\hline & $\mathrm{n}$ & 68 & 68 & 68 & 68 & 68 \\
\hline \multirow{3}{*}{ Faecal streptococci $(\mathrm{Sf})$} & Pearson correlation & 0,043 & 0,217 & $0.226^{*}$ & 1 & 0,078 \\
\hline & GIS. (bilateral) & 0,728 & 0,075 & 0,043 & & 0,528 \\
\hline & $\mathrm{n}$ & 68 & 68 & 68 & 68 & 68 \\
\hline \multirow{3}{*}{ Anaerobics sulphito-reducings (ASR) } & Pearson correlation & $-0,012$ & 0,069 & 0,031 & 0,078 & 1 \\
\hline & GIS. (bilateral) & 0,920 & 0,577 & 0,803 & 0,528 & \\
\hline & $\mathrm{n}$ & 68 & 68 & 68 & 68 & 68 \\
\hline \multicolumn{7}{|c|}{$\begin{array}{l}\text { Legend : } \\
\text { **. Correlation is significant (Sig.) at level } 0.01 \text { (bilateral). } \\
\text { *. The correlation is significant (Sig.) at level } 0.05 \text { (bilateral). } \\
\text { N. Number of samples analyzed } \\
\text { GIS : coefficient of correlation }\end{array}$} \\
\hline
\end{tabular}

\section{Main component analyzis}

The main component analysis shown in Figure 4 made it possible to group two components according to the correlation. The 1st component includes bacteria indicating hygiene violations (FAMT, CT, Cth) and a bacterium indicating recent fecal contamination (Sf) and the second includes bacteria indicating ancient fecal contamination (ASR).

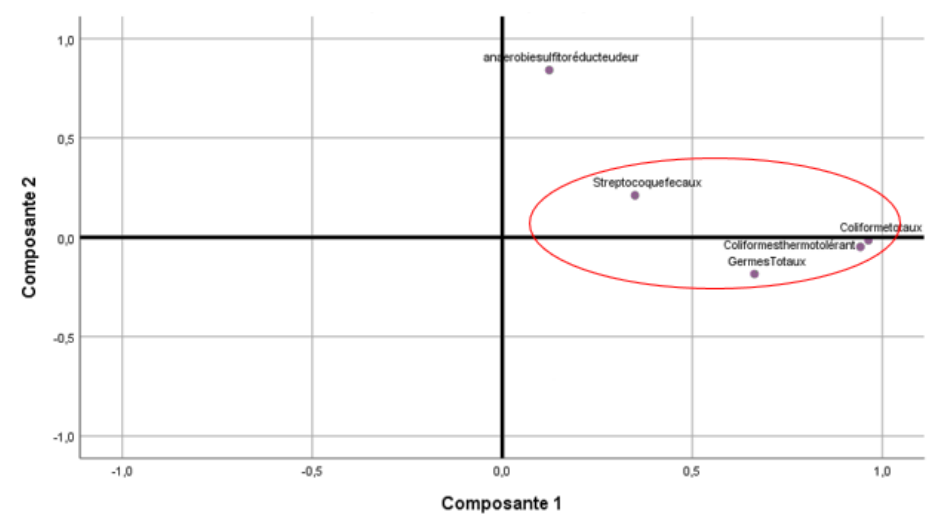

Figure 4 Correlations between the germs sought.

\section{DISCUSSION}

The objective of this study was to assess the bacteriological quality of the drilling water of four prefectures in the savannah region. The results indicated that the water analyzed was contaminated with most of the germs sought according to the EU criteria (2007). The breach of hygiene rules was significant in the prefectures of Tône, and Oti respectively of $91.7-100 \%$ and $57.1-69.2 \%$ compared to the Total Mesophilic Aerobic Flora, total coliforms and thermotolerant coliforms. Similar studies on the quality of drilling water in Côte d'Ivoire (Amin et al., 2019), Niger (Ocheli et al., 2020), Algeria (Ghaleb and Mokrani, 2019; Tabouche and Achour, 2010), Nigeria (Aromolaran et al., 2019), Cameroon (Nya, 2020), Togo (Soncy et al., 2015) found that FAMT, CT and Cth were mainly responsible for the poor quality of the waters studied. In addition, according to some authors who have worked on well water, groundwater contamination may be caused by soil permeability, groundwater depth, absence or inadequacy of sanitation works, poor garbage management and the method of drawing (Tabouche and Achour, 2010; Yapo et al., 2010; Bouchemal and Achour, 2015; Dougna et al., 2015; Mulamattathil et al., 2015).

Sulfito-Reducer Anaerobes (ASR) were detected in eight borehole water samples, six from Tône Prefecture and two from Oti Prefecture. The presence of these germs in the waters studied could be justified by long-standing contamination of the water table due to the infiltration of wastewater from the sanitary facilities of the populations of the study area and a low dissolved oxygen content. According to Lutterodt et al.(2018); Ukah et al.(2018), Adamou et al.(2020) and Kaboré et al.(2020), sewage from sewage systems, septic tanks and solid waste are the main 
sources of groundwater pollution. Unfortunately, the water from these boreholes is used for human consumption (kitchen, dishes, washing clothes...) and animal by the beneficiary populations of that region.

The descriptive statistical analysis of the germs sought in the 68 samples of borehole water from the four prefectures of the savannah region revealed bacterial loads well above the threshold (FAMT $>10^{3} \mathrm{CFU} / \mathrm{ml}, \mathrm{CT}>1 \mathrm{CFU} / 100 \mathrm{ml}, \mathrm{Cth}>1$ $\mathrm{CFU} / 100 \mathrm{ml}, \mathrm{Sf}>2 \mathrm{CFU} / 20 \mathrm{ml}$ ) set by the criteria and guidelines of the European Union for water intended for human consumption. The authors (Soncy et al., 2015) and (Sokegbe et al., 2017) made the same observations during their studies on the assessment of the bacteriological quality of well and drilling water in Lomé (Togo). The large load of AWF, although largely non-pathogenic, could lead to suspicion of other pathogenic microorganisms (Djeri et al., 2019; Soncy et al., 2019; Toure et al., 2019). In addition to the presence of germs responsible for breach of hygiene rules (FAMT, total coliforms, and thermotolerant coliforms), there is correlation between indicators of recent faecal contamination and germs responsible for failure to comply with hygiene rules. This is justified by the highly significant positive correlation $(\mathrm{P}<0,01)$ noted between these germs and which made it possible to distinguish two groups of germs namely the bacteria indicating a breach of hygiene rules and that indicating a recent fecal contamination. Thus, the search for one of these microorganisms would therefore predict the dynamics of germs of recent faecal contamination (E.coli, Salmonella sp and Streptococcus $s p$.) and therefore, to judge the bacteriological quality of their biotope and the potential epidemiological risk represented by their consumption without treatment.

\section{CONCLUSION}

It emerges that the drilling water analyzed is polluted by germs indicating violation of hygiene rules with nearly $90 \%$ of drilling contaminated by the FAMT and $50 \%$ of drilling by total coliforms. The existing correlation between bacteria indicative of contamination will make it possible to predict the quality and risks of gastroenteritis for consumers. Another study will be conducte for the molecular characteristic and antibiotic succeptibility of the differents bacteria isolated in this study.

\section{REFERENCES}

Adamou, H., Ibrahim, B., Salack, S., Adamou, R., Sanfo, S., \& Liersch, S. (2020). Physico-chemical and bacteriological quality of groundwater in a rural area of Western Niger: a case study of Bonkoukou. Journal of water and health, 18(1), 77-90. https://doi.org/10.2166/wh.2020.082

Amin, C. N., Dibi, K. S., Yapo, W. T., Able, C. N., Kpaibé, P. A. S., Kouadio, L., \& Malan, A. (2019). Chemical and Bacteriological Control of Drinking Water from 15 Villages in Côte d'Ivoire. International Journal of Nutrition and Food Sciences, 7(6), 180. https://doi.org/10.11648/j.ijnfs.20180706.11

Antwi-Agyei, P., Biran, A., Peasey, A., Bruce, J., \& Ensink, J. (2016). A faecal exposure assessment of farm workers in Accra, Ghana: a cross sectional study. BMC Public Health, 16(1), 1-13. https://doi.org/10.1186/s12889-016-3266-8

Aromolaran, O., Fagade, O. E., Aromolaran, O. K., Faleye, E. T., \& Faerber, H. (2019). Assessment of groundwater pollution near Aba-Eku municipal solid waste dumpsite. Environmental monitoring and assessment, 191(12), 1-25. https://doi.org/10.1007/s10661-019-7886-1

Bouchemal, F. (2015). Qualité physico-chimique et paramètres de pollution des eaux souterraines de la région de Biskra. Larhyss Journal, 12(2), 197-212.

DGSCN, 2007. Profil de la pauvreté 2006, établi à partir de l'enquête QUIBB. Page 1517.

Djeri, B., Kogno, E., Bilakema, K., Kangni-Dossou, M., Soncy, K., Taale, E., \& Ameyapoh, Y. (2019). Socio-sanitary Aspects and Microbiological Quality of Drinking Water in the Prefecture of Golfe (Togo). European Scientific Journal, ESJ, 15(21), 268. https://doi.org/10.19044/esj.2019.v15n21p268

Dougna, A. A., Gnazou, M. D. T., Kodom, T., Djaneye-Boundjou, G., \& Bawa, M. L. (2015). Physico-chimie et qualité des eaux des forages d'hydraulique villageoise dans la région centrale au Togo. International Journal of Biological and Chemical Sciences, 9(4), 2249-2262.

Fisher, M.B., Danquah, L., Seidu, Z., Fechter, A.N., Saga, B., Bartram, J.K., Liang, K.M., Ramaswamy, R., 2020. WaSH CQI: Applying continuous quality improvement methods to water service delivery in four districts of rural northern Ghana. PloS one 15, e0233679. https ://doi.org/10.4314/ijbcs.v9i4.42

Ghaleb, Z., \& Mokrani, K. (2019). Amélioration de la qualité physico-chimique et bactériologique par filtre élaboré des eaux de forages de Boukhalfa (Doctoral dissertation, Université Mouloud Mammeri). https://vrelex.ummto.dz/handle/ummto/9380.

Igbinosa, I. H., \& Aighewi, I. T. (2017). Quality assessment and public health status of harvested rainwater in a peri-urban community in Edo State of Nigeria. Environmental monitoring and assessment, 189(8), 1-12. https://doi.org/10.1007/s10661-017-6122-0
Kaboré, A., Zongo, I., Savadogo, B., Sawadogo, J., Kaboré, D., Nikiema, L. Z., \& Savadogo, P. W. (2020). Evaluation de la qualité physicochimique de l'eau des forages dans la région du centrenord au Burkina Faso: Cas des écoles primaires. International Journal of Innovation and Applied Studies, 29(4), 1349-1357.

Kankandja, P. M., \& Sokemawu, K. (2017, September). Territorialité, autochtonie et ethnicité: des fondamentaux liés à l'accès aux eaux pastorales dans la Région des Savanes au nord Togo. In Colloque de l'UAC. https://hal.archives-ouvertes.fr/hal01968635/

Kumpel, E., Albert, J., Peletz, R., de Waal, D., Hirn, M., Danilenko, A., ... \& Khush, R. (2016). Urban water services in fragile states: an analysis of drinking water sources and quality in Port Harcourt, Nigeria, and Monrovia, Liberia. The American journal of tropical medicine and hygiene, 95(1), 229. https ://doi.org/10.4269/ajtmh.15-0766

Lutterodt, G., Van de Vossenberg, J., Hoiting, Y., Kamara, A. K., Oduro-Kwarteng, S., \& Foppen, J. W. A. (2018). Microbial groundwater quality status of hand-dug wells and boreholes in the Dodowa area of Ghana. International Journal of Environmental Research and Public Health, 15(4), 730. https://doi.org/10.3390/ijerph15040730

Mulamattathil, S. G., Bezuidenhout, C., \& Mbewe, M. (2015). Analysis of physicochemical and bacteriological quality of drinking water in Mafikeng, South Africa. Journal of water and health, 13(4), 1143-1152. https://doi.org/10.2166/wh.2015.273

Ngure, F., Gelli, A., Becquey, E., Ganaba, R., Headey, D., Huybregts, L., ... \& Zongrone, A. (2019). Exposure to livestock feces and water quality, sanitation, and hygiene (wash) conditions among caregivers and young children: Formative research in rural Burkina Faso. The American journal of tropical medicine and hygiene, 100(4), 998. https ://doi.org/10.4269/ajtmh.18-0333

Nya, E. (2020). ACCES A L'EAU POTABLE ET A L'ASSAINISSEMENT DANS LE DEPARTEMENT DU NDE (REGION DE L'OUEST-CAMEROUN) (Doctoral dissertation, Université de Yaoundé I (Cameroun)). https://tel.archives-ouvertes.fr/tel$\underline{02937356}$

Ocheli, A., Otuya, O. B., \& Umayah, S. O. (2020). Appraising the risk level of physicochemical and bacteriological twin contaminants of water resources in part of the western Niger Delta region. Environmental monitoring and assessment, 192(5), 1-16. https://doi.org/10.1007/s10661-020-08302-5

Sokegbe, O. Y., Djeri, B., Kogno, E., Kangnidossou, M., Mensah, R. T., Soncy, K., \& Ameyapoh, Y. (2017). Les risques sanitaires liés aux sources d'eau de boisson dans le district $\mathrm{n} 2$ de Lomé-commune: cas du quartier d'Adakpamé. International Journal of Biological and Chemical Sciences, 11(5), 2341-2351. https :doi.org/10.4314/ijbcs.v11i5.31

Soncy, K., Anani, K., Djeri, B., Adjrah, Y., Karou, D. S., Ameyapoh, Y., \& de Souza, C. (2019). Assessment of microbial contamination risks factors and safety of out of home food in Lomé-Togo. Int. J. Food. Res. 6(1) 1-8. doi.org/10.33500/ijfr.2019.06.001 Soncy, K., Djeri, B., Anani, K., Eklou-Lawson, M., Adjrah, Y., Karou, D. S., ... \& De Souza, C. (2015). Évaluation de la qualité bactériologique des eaux de puits et de forage à Lomé, Togo. Journal of Applied Biosciences, 91, 8464-8469. https ://doi.org/10.4314/jab.v91i1.6

Tabouche, N., \& Achour, S. (2010). Etude de la qualité des eaux souterraines de la région orientale du Sahara septentrional algérien. LARHYSS Journal P-ISSN $1112-$ 3680/E-ISSN 2521-9782, (3).

Toure, A., Wenbiao, D., Keita, Z., Dembele, A., \& Abdalla Elzaki, E. E. (2019). Drinking water quality and risk for human health in Pelengana commune, Segou, Mali. Journal of water and health, 17(4), 609-621. https://doi.org/10.2166/wh.2019.004

Ukah, B. U., Igwe, O., \& Ameh, P. (2018). The impact of industrial wastewater on the physicochemical and microbiological characteristics of groundwater in Ajao-Estate Lagos, Nigeria. Environmental monitoring and assessment, 190(4), 1-17. https://doi.org/10.1007/s10661-018-6600-z

World Health Organization. (2019). Progress on household drinking water, sanitation and hygiene 2000-2017: special focus on inequalities. World Health Organization. https://apps.who.int/iris/bitstream/handle/10665/329370/9789241516235-eng.pdf World Health Organization. (2019). Water, sanitation, hygiene and health: a primer for health professionals (No. WHO/CED/PHE/WSH/19.149). World Health Organization. Yapo, O., Mambo, V., Seka, A., Ohou, M. J. A., Konan, F., Gouzile, V., ... \& Houenou, P. (2010). Evaluation de la qualité des eaux de puits à usage domestique dans les quartiers défavorisés de quatre communes d'Abidjan (Côte d'Ivoire): Koumassi, Marcory, Port-Bouet et Treichville. International Journal of Biological and Chemical Sciences, 4(2). https://doi.org/10.4314/ijbcs.v4i2.58111 